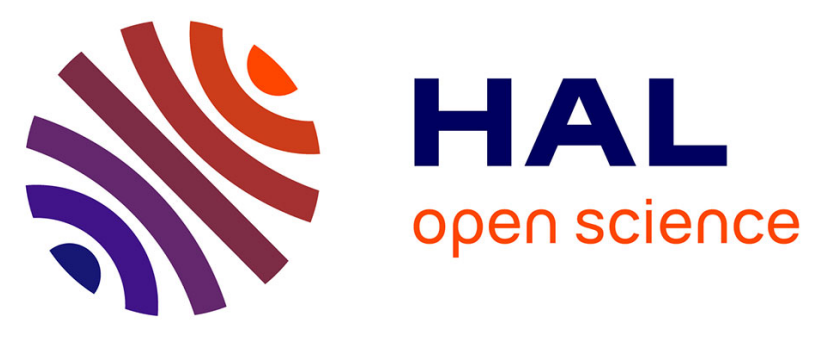

\title{
Quantitative mRNA analysis of serotonin 5-HT4 receptor isoforms, calcium handling proteins and ion channels in human atrial fibrillation
}

Frank Lezoualc'h, Klaudia Steplewski, Laura Sartiani, Alessandro Mugelli, Rodolphe Fischmeister, Antoine Bril

\section{To cite this version:}

Frank Lezoualc'h, Klaudia Steplewski, Laura Sartiani, Alessandro Mugelli, Rodolphe Fischmeister, et al.. Quantitative mRNA analysis of serotonin 5-HT4 receptor isoforms, calcium handling proteins and ion channels in human atrial fibrillation. Biochemical and Biophysical Research Communications, 2007, 357 (1), pp.218-224. 10.1016/j.bbrc.2007.03.124 . hal-02942090

\author{
HAL Id: hal-02942090 \\ https://hal.science/hal-02942090
}

Submitted on 17 Sep 2020

HAL is a multi-disciplinary open access archive for the deposit and dissemination of scientific research documents, whether they are published or not. The documents may come from teaching and research institutions in France or abroad, or from public or private research centers.
L'archive ouverte pluridisciplinaire HAL, est destinée au dépôt et à la diffusion de documents scientifiques de niveau recherche, publiés ou non, émanant des établissements d'enseignement et de recherche français ou étrangers, des laboratoires publics ou privés. 


\title{
Quantitative mRNA analysis of serotonin 5-HT 4 receptor isoforms, calcium handling proteins and ion channels in human atrial fibrillation
}

\author{
Frank Lezoualc'h ${ }^{\text {a,b }}$, Khudia Steplewski', Laura Sartiani ${ }^{\text {, }}$ Alessandro Mugelli ${ }^{\text {, }}$ \\ Rodolphe Fischmeister ${ }^{a, b, *}$, Antoine Bril ${ }^{\mathrm{c}, \#}$
}

\author{
${ }^{a}$ INSERM, U769, F-92296 Châtenay-Malabry, France \\ ${ }^{b}$ Univ. Paris-Sud 11, IFR-141, F-92296 Châtenay-Malabry, France \\ ${ }^{c}$ GlaxoSmithKline Pharmaceuticals, King of Prussia, Pennsylvania 19406-0939, USA \\ ${ }^{d}$ Dipartimento di Farmacologia Preclinica e Clinica, Universita degli Studi, 50139 Firenze, \\ Italy
}

*Corresponding author: INSERM U769, Faculté de Pharmacie, Univ ersité Paris-Sud 11, 5 Rue Jean-Baptiste Clément, F-92296 Châtenay-Malabry, France.

Tel.: 33-1-46 8357 57, fax: 33-1-46 835475.

E-mail address: fisch@vjf.inserm.fr (R. Fischmeister)

\#Present a ddress: IdRS, 11 rue des Moulineaux, F-92150 Suresnes, France. Tel.: 3315572 24 24; Fax: 33155722640 ; E-mail: antoine.bril@fr.netgrs.com 
Abstract Seroton in 5- $\mathrm{HT}_{4}$ receptors are present in human atrial myocytes and have been proposed to contribute to the generation of atrial fibrillation (AF). Here, we quantified 5- $\mathrm{HT}_{4}$ receptors as well as other key genes involved in cardiac rhythm and contraction in right atrial appendages of patients with chronic $\mathrm{AF}(\mathrm{CAF})$ and acute $\mathrm{AF}(\mathrm{AAF})$. Right atrial appendages were obtained from eleven patients in sinus rhythm (SR), five with AAF and six with CAF ( $>12$ months). TaqMan real time quantitative RT-PCR was performed on total RNA. Results were normalised to the average of three housekeeping genes, cyclophilin, GADPH and RL19. The rank order of expression of $\mathrm{h} 5-\mathrm{HT}_{4}$ receptors variants was $(\mathrm{b})>(\mathrm{a})>(\mathrm{g})>(\mathrm{c})$ in the group of patients in SR. In AAF, we found a strong decrease in $\mathrm{h} 5-\mathrm{HT}_{4(\mathrm{~b})}, \mathrm{h} 5-\mathrm{HT}_{4(\mathrm{c})}$ and h5$\mathrm{HT}_{4(\mathrm{~g})}$ transcripts. In CAF patients, the mRNA expression level of the $\mathrm{h} 5-\mathrm{HT}_{4(\mathrm{~b})}$ isoform significantly increased two fold versus SR. A similar increase was reported for $\beta_{1}$-adrenergic receptor, connexin 43 and the L-type $\mathrm{Ca}^{2+}$ channel CaCNA1C subunit. Interestingly, CAF was associated with a strong increase in the expression of $\mathrm{Na}^{+} / \mathrm{Ca}^{2+}$ exchanger and the voltage-dependent $\mathrm{Na}^{+}$channel SCN5A subunit. Our results indicate that $\mathrm{h} 5-\mathrm{HT}_{4(\mathrm{~b})}$ is the dominant cardiac isoform of human $5-\mathrm{HT}_{4}$ receptors and its expression is increased in CAF. These data support the involvement of 5- $\mathrm{HT}_{4}$ receptors in atrial arrhythmia.

Keywords Arrhythmia - serotonin $-G$ protein-coupled receptor - calcium handling proteins - channel currents 


\section{Introduction}

Atrial fibrillation (AF) is the most common sustained arrhythmia in the Western world and its prevalence is increasing with age (1). AF is frequently observed in patients with hypertension and ischemic heart disease, being more common in patients having congestive heart failure (2;3). In addition, transient atrial fibrillation appears postsurgically in approximately one third of patients undergoing coronary artery bypass surgery (4). Although some progress has been made in the therapy and prevention of atrial arrhythmia and particularly of atrial fibrillation, the use of antiarrhythmic drugs that modulate cardiac ion channels is associated with organ toxicity and potential ventricular proarrhythmic effects $(5 ; 6)$. Consequently novel and safe therapeutic approaches need to be developed.

Electrophysiological remodelling is a central event in AF and is characterised by the shortening of the atrial effective refractory period (AERP). It is associated with changes in gene expression and functional properties of key proteins involved in ion transport $(2 ; 7)$. Therefore, one possible approach for the treatment of $\mathrm{AF}$ is the development of antiarrhythmic drugs which target membrane receptors specifically involved in the regulation of cellular electrophysiology of atrial cardiomyocytes. One such receptor which has gained attention for its involvement in $\mathrm{AF}$ is the serotonin $5-\mathrm{HT}_{4}$ receptor $(8-10)$.

Several splice variants of the human $5-\mathrm{HT}_{4}$ receptor $\left(\mathrm{h} 5-\mathrm{HT}_{4}\right)$ have been described, particularly at the $\mathrm{C}$-terminus where alternative splicing results in divergent sequences following Leu358 (10). These $\mathrm{h} 5-\mathrm{HT}_{4}$ receptor isoforms belong to the family of seven transmembrane domain G-protein coupled receptors (GPCRs) which activ ate adenylyl cyclase (10;11). 5-HT 4 receptor activation leads to strong positive chronotropic, inotropic and lusitropic effects in human and pig atrium (8) through activation of the cAMP/PKA pathway and stimulation of several key components of the excitation-contraction coupling such as the L-type $\mathrm{Ca}^{2+}$ channel current $\left(\mathrm{I}_{\mathrm{Ca}, \mathrm{L}}\right)(12 ; 13)$ and the hyperpolarization-activated pacemaker 
current $I_{f}(14)$. Although expressed at the mRNA level in human ventricle $(15 ; 16), 5-\mathrm{HT}_{4}$ receptor activation does not normally exert any effect on contractility $(16 ; 17)$ or $\mathrm{I}_{\mathrm{Ca}, \mathrm{L}}(12)$ in this tissue. However, expression level of the $5-\mathrm{HT}_{4}$ receptor in the ventricle was recently found to increase in a rat model of heart failure (18) and this is accompanied by the appearance of a positive inotropic effect upon receptor activation $(18 ; 19)$. This indicates that the $5-\mathrm{HT}_{4}$ receptor may undergo changes in its expression level and function depending on the pathophysiological state of the cardiac tissue.

The preferential location of the $5-\mathrm{HT}_{4}$ receptor in the atrium, together with its stimulatory effect on arrhythmogenic currents such as $\mathrm{I}_{\mathrm{Ca}, \mathrm{L}}$ and $\mathrm{I}_{\mathrm{f}}$, makes it reasonable to assume that the 5- $\mathrm{HT}_{4}$ receptor participates in the control of cardiac rhythmic and/or arrhythmic activity (8). In support of this hypothesis, RS-100302, a 5- $\mathrm{HT}_{4}$ receptor antagonist, inhibited AF induced by rapid pacing in juvenile pigs (20). Thus, $5-\mathrm{HT}_{4}$ receptors may represent a new potential therapeutic target for the prevention or treatment of $\mathrm{AF}$.

To date, there is no detailed information on the expression levels of the different h5- $\mathrm{HT}_{4}$ receptor isoforms in human atrium, both in normal and pathological tissues. One major drawback of the study of $5-\mathrm{HT}_{4}$ receptor expression in human atrium is its very low density which renders its detection rather difficult by classical biochemical techniques (21). In addition, specific antibodies against the different $5-\mathrm{HT}_{4}$ splice variants are not yet available. But most importantly, selective ligands for the different $5-\mathrm{HT}_{4}$ receptor isoforms are still lacking and this excludes the feasibility of any functional study which aims at elucidating the role of the different $5-\mathrm{HT}_{4}$ splice variants in native tissues (10). In this study, we therefore performed the quantification of cardiac $\mathrm{h} 5-\mathrm{HT}_{4}$ receptors transcripts by TaqMan reverse transcriptase-polymerase chain reaction (RT-PCR). mRNA expression levels of the cardiac h5-HT 4 receptor C-terminal splice variants h5-HT $4(\mathrm{a}), \mathrm{h}_{5}-\mathrm{HT}_{4(\mathrm{~b})}, \mathrm{h} 5-\mathrm{HT}_{4(\mathrm{c})}$, and h5-HT $4(\mathrm{~g})$ were quantified in right atrial appendages of patients with chronic AF (CAF) and acute AF (AAF) 
following coronary artery bypass grafting $(\mathrm{CABG})$. Furthermore, the expression levels of a whole panel of key genes involved in cardiac rhythm and contraction were investigated.

\section{Methods}

The investigation conforms with the principles outlined in the Declaration Helsinki and was approved by the local ethical committee; informed consent was obtained before cardiac surgery. Patients underwent coronary artery bypass grafting (CABG, n=19), CABG plus aortic valve replacement $(n=2)$ and mitral valve replacement $(n=1)$. Specimens of right atrial appendages were obtained as part of the routine atriotomy procedure and were immediately frozen in liquid nitrogen. Methods used for RNA preparation, real-time quantitative RT-PCR and statistical analysis are detailed in the online Supplementary Data to this article.

\section{Results and Discussion}

\section{Patients}

Twenty two patients undergoing cardiac surgery were studied: all the patients were electrocardiographically monitored all over the period of hospitalization. They were divided in three different groups: sinus rhythm (SR), patients in SR who did not develop atrial fibrillation after card iac surgery; acute atrial fibrillation (AAF), patients in SR who developed atrial fibrillation after surgery; chronic atrial fibrillation (CAF), patients with documented permanent atrial fibrillation from at least one year before cardiac surgery. Pre-surgical pharmacological therapy and the main clinical and demographic characteristics of the patients are given in Table 1. 


\section{mRNA expression analys is of $5-\mathrm{HT}_{4}$ receptor isoforms in human atrial samples}

We investigated the expression of $\mathrm{h} 5-\mathrm{HT}_{4}$ receptor C-terminal splice variants in the three groups of patients either with sinus rhythm (SR, $n=11)$, or developing AAF $(n=5)$ or CAF (n=6) (Fig. 1). The h5-HT4(b) receptor isoform was consistently 15-23 fold higher than h5$\mathrm{HT}_{4(\mathrm{c})}$ and $\mathrm{h} 5-\mathrm{HT}_{4(\mathrm{~g})}$ receptors in SR group, which were quite similar to each other but a further 2-3 fold higher than h5-HT 4 (a) (Fig. 1). As previously shown by non-quantitative RTPCR (11), we were unable to detect any messenger en coding the $\mathrm{h} 5-\mathrm{HT}_{4(\mathrm{~d})}$ receptor isoform in human atrial samples (data not shown). These results indicate that, like in the central nervous system and peripheral tissues such as the small in testine (22), the $\mathrm{h}_{5}-\mathrm{HT}_{4(\mathrm{~b})}$ receptor isoform is the predominant splice variant expressed in human atria. We then compared the expression profile of $\mathrm{h} 5-\mathrm{HT}_{4}$ receptor isoforms in the groups of AAF and CAF patients to the group of controls in SR (Fig. 1). We found a drop in the expression levels of the h5-HT 4 (b) splice variants in the group of AAF patients (Fig. 1). In this group, the rank order of expression of $\mathrm{h} 5-\mathrm{HT}_{4}$ receptors variants was $(\mathrm{a})=(\mathrm{b})=(\mathrm{c})>(\mathrm{g})$ indicating that the predominance of the $(\mathrm{b})$ isoform in SR patients was completely lost in AAF patients. Regarding the group of CAF patients, we observed a significant increase in the expression level of the $\mathrm{h} 5-\mathrm{HT}_{4(\mathrm{~b})}$ receptor isoform which was 2 fold higher than that observed in the SR group (Fig. 1). As observed in the group of patients in $\mathrm{SR}$, the $\mathrm{h} 5-\mathrm{HT}_{4(\mathrm{~b})}$ splice variant remained the predominant $5-\mathrm{HT}_{4}$ receptor isoform expressed in the $\mathrm{CAF}$ group, with a rank order of abundance for the different isoforms $\mathrm{b}>\mathrm{a}=\mathrm{c}>\mathrm{g}$ (Fig. 1). The observed differences in $5-\mathrm{HT}_{4}$ receptor isoform levels were not due to differences in primer/probe characteristics since we have previously demonstrated that the primer/probe set for $\mathrm{h} 5-\mathrm{HT}_{4(\mathrm{~b})}$ was slightly less efficient than the primer/probe sets for the other variants (22). The observed up-regulation of the major 5-HT 4 (b) receptor isoform in patients with CAF contrasts with work from Grammer and colleagues (23) who found a slight decrease (36\%) in the amount of 5- $\mathrm{HT}_{4}$ receptor in mRNA in atrial tissues of patients with 
CAF. A reason for this discrepancy could reside in the technique employed by the authors to quantify $5-\mathrm{HT}_{4}$ receptors. Indeed, they used semi-quan titative RT-PCR which is a much less sensitive technique than TaqMan RT-PCR performed in our study. Alternatively, the duration of AF could also be a factor that might influence the expression of 5- $\mathrm{HT}_{4}$ receptors in the atrium. Indeed, Grammer and colleagues (23) included patients who had CAF for more than one month whereas we selected patients affected by CAF for more than one year. In agreement with this hypothesis, we found a significant decrease in the expression of the 5$\mathrm{HT}_{4(\mathrm{~b})}$ receptors in patients with AAF following CABG.

\section{mRNA expression of GPCRs and calcium handling proteins in AF}

$5-\mathrm{HT}_{4}$ receptors share some similarities with $\beta$-adrenergic receptors in their signalling cascade and their effects on ion channels (10;24). Therefore, we analysed mRNA expression levels of $\beta_{1^{-}}\left(\beta_{1-A R}\right)$ and $\beta_{2^{-}}\left(\beta_{2^{-}} \mathrm{AR}\right)$ adrenergic receptors in right atrial appendages of patients in sinus rhythm, and with AAF or CAF (Fig. 2). In accordance with a previous study (23), we observed a significant increase in $\beta_{1}$-AR expression in the group of CAF patients as compared to SR and AAF groups whereas no significant changes were detected for $\beta_{2}$-AR transcripts between the three groups of patients (Fig. 2). Other GPCRs such as the $M_{2} R$ and $\mathrm{AT}_{1}-\mathrm{R}$ and $\mathrm{AT}_{2}-\mathrm{R}$ receptors which have been shown to be involved in the structural remodelling occurring in AF (25), were also assayed by TaqMan real time RT-PCR (Fig. 2). Although we found a tendency for an increase in the expression of theses genes in patients developing AAF vs. SR group, these changes did not reach statistical significance (Fig. 2). Furthermore, no changes in the mRNA expression of $\mathrm{AT}_{1}-\mathrm{R}$ and $\mathrm{AT}_{2}-\mathrm{R}$ were observed in CAF. This is supported by another study which has shown that the expression of AT-R proteins is regulated at post-transcriptional levels in $\mathrm{AF}(25)$. 
Because cytosolic calcium abnormalities are important mediators of AF (26), gene expression of proteins influencing calcium handling was also investigated (Fig. 2). Although it has been reported that AF may down regulate the expression of SERCA2a and up regulate the expression of $1,4,5$ trisphosphate receptor $\left(\mathrm{IP}_{3} \mathrm{R}\right)$, respectively (27-29), we did not find any significant changes in mRNA expression of SERCA2a, IP ${ }_{3} R$ or RYR2 between the group of SR, AAF and CAF patients (Fig. 2). Interestingly, we detected a strong increase in the expression level of NCX in patients with CAF (Fig. 2). Indeed, expression level of NCX mRNA in the group of patients with CAF was more than 7 fold higher than that in SR (Fig. 2). The amount of NCX transcripts was also significantly increased in the group of AAF patients, albeit to a lower extent (Fig. 2). These results are in accordance with a recent study (30). Under physiologic conditions, NCX extrudes intracellular $\mathrm{Ca}^{2+}$ during diastole (24). In contrast, NCX is over expressed in heart failure and has been shown to contribute to both contractile dysfunction and arrhythmogenesis (31). Therefore, one could speculate that the high increase in the expression of NCX observed in CAF in the present study might contribute to the induction and maintenance of atrial electrical remodelling and contractile dysfunction.

\section{Gene expression of ion channels}

$\mathrm{CAF}$ is associated with a sustained shortening of the atrial action potential duration and AERP (7;26). AERP involves functional changes in ion channels, particularly in repolarizing $\mathrm{K}^{+}$ channel activity (32;33). We therefore investigated whether AAF and CAF are associated with any change in the expression levels of repolarizing outward $\mathrm{K}^{+}$channel subunits such as KCN5 (Kv1.5), Kv4.3 and HERG. No significant changes were found for Kv1.5, Kv4.3 and HERG mRNA levels in either group (Fig. 3A). Interestingly, a significant reduction in a cardiac pacemaker channel, HCN4 was observed in the group of patients with CAF (Fig. 3A). 
Transcripts of two other members of this family, HCN1 and HCN2 were not significantly altered (Fig. 3A).

Besides repolarizing outward $\mathrm{K}^{+}$channels, L-type $\mathrm{Ca}^{2+}$ channel reduction also contributes to shortening the AERP and action potential duration $(32 ; 34)$. Unexpectedly, we found that CAF was associated with a significant increase in the mRNA amount of L-type $\mathrm{Ca}^{2+}$ channel $\alpha_{1 \mathrm{C}}$ subunit (CaCNA1C) as compared to the group in SR and AAF, whereas no changes were observed in the expression of T-type $\mathrm{Ca}^{2+}$ channel $\alpha_{1 \mathrm{H}}(\mathrm{CaCNA} 1 \mathrm{H})$ and $\alpha_{1 \mathrm{G}}(\mathrm{CaCNA} 1 \mathrm{G})$ subunits between the three groups of patients (Fig. 3B). The fact that we observed a simultaneous up-regulation of the major $5-\mathrm{HT}_{4(\mathrm{~b})}$ receptor isoform and the L-type $\mathrm{Ca}^{2+}$ channel $\alpha_{1 \mathrm{C}}$ subunit in patients with CAF might lead to excessive activation of $\mathrm{I}_{\mathrm{Ca}, \mathrm{L}}$ by $5-\mathrm{HT}_{4}$ receptors, causing intracellular calcium overload resulting in delayed after-depolarizations and triggered activity (8). While our results contrast with previous findings showing that $\mathrm{I}_{\mathrm{Ca}, \mathrm{L}}$ amplitude as well as the gene expression of L-type $\mathrm{Ca}^{2+}$ channel $\alpha_{1 \mathrm{C}}$ subunit and HERG, and Kv4.3 are significantly reduced in CAF $(27 ; 28 ; 35 ; 36)$, Schotten and colleagues (37) recently found no change in the protein expression of the L-type $\mathrm{Ca}^{2+}$ channel $\alpha_{1}$ and $\beta_{2}$ subunits in CAF. Altogether, these observations suggest that the regulation of the L-type $\mathrm{Ca}^{2+}$ channel is particularly complex in AF.

Expression of the voltage-dependent $\mathrm{Na}^{+}$channel $\left(\mathrm{I}_{\mathrm{Na}}\right)$ SCN5A subunit paralleled the observed increase in L-type $\mathrm{Ca}^{2+}$ channel (Fig. 3B), whereas it was found to be unaltered in another study on human AF (27). Moreover, both the mRNA (34) and the density of $\mathrm{I}_{\mathrm{Na}}$ (38;39) were found to decrease in a dog model of atrial fibrillation. Although the exact reasons for the discrepancies between the expression level of different ion channel genes in our study and those mentioned above are unknown, one could argue that these discrepancies may be due to methodological differences (TaqMan real time quantitative RT-PCR in our study vs. semi-quantitative RT-PCR in the other ones), differences in patients' medication and 
clinical parameters, in particular the duration of persistent AF ( $>1$ year in this study $v s .>1-3$ months in others), and differences in AF models (human AF vs. dog model of AF induced by rapid-pacing).

Since altered expression of gap junction proteins (connexins) in diseased myocardial tissue may lead to abnormal electrical coupling between cardiomyocytes and hence contribute to arrhythmogenesis (40), we examined the expression of $\mathrm{Cx} 40$ and $\mathrm{Cx} 43$. Previous studies performed in animal models of AF reported contradictory results (40). Although, Cx43 expression is increased in canine model of AF (41) it is unaltered in the goat (42). Another study in human showed that Cx40 mRNA was expressed at significantly higher levels in patients who developed postoperative AF than those who did not (43). In the same study, the amounts of $\mathrm{Cx} 43$ were not significantly different between the groups. Here, we found that Cx43 was significantly increased in the group of CAF as compared to SR patients (Fig. 3B) but no significant change in Cx43 expression level was observed in AAF patients.

In conclusion, we have shown that the $5-\mathrm{HT}_{4(\mathrm{~b})}$ receptor isoform is the most preponderant

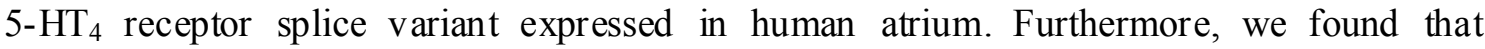
seroton in 5- $\mathrm{HT}_{4}$ receptor transcripts are differentially regulated in AAF and CAF. The upregulation of $5-\mathrm{HT}_{4(\mathrm{~b})}$ receptor isoform in $\mathrm{CAF}$ supports the involvement of 5- $\mathrm{HT}_{4}$ receptors in atrial arrhythmia and the potential therapeutic utility of 5- $\mathrm{HT}_{4}$ receptor antagonists in this cardiac disorder. The increase in $\mathrm{I}_{\mathrm{Na}}$ channel expression together with an increased expression of NCX may reinforce the hypothesis that arrhythmogenesis in CAF is enhanced and could provide a molecular basis for the "AF begets AF" theory (2). Further experiments are required to determine whether these proteins are modulated in a similar manner at the protein or functional level in AF. These await the production of specific 
antibodies against the different $5-\mathrm{HT}_{4}$ splice variants and selective ligands for the different 5$\mathrm{HT}_{4}$ receptor isoforms.

\section{Acknowledgment}

This work has been partly supported by a grant from MIUR (Cofin "New insights into mechanisms, prevention and therapy of atrial fibrillation"). 


\section{References}

1. G. Chatap, K. Giraud, J.P. Vincent, Atrial fibrillation in the elderly - Facts and management, Drugs \& Aging 19 (2002) 819-846.

2. M.A. Allessie, P.A. Boyden, A.J. Camm, A.G. Kleber, M.J. Lab, M.J. Legato, M.R. Rosen, P.J. Schwartz, P.M. Spooner, D.R. Van Wagoner, A.L. Waldo, Pathophysio logy and prevention of atrial fibrillation, Circulation 103(2001) 769-777.

3. E.K. Heist, J.N. Ruskin, Atrial fibrillation and congestive heart failure: risk factors, mechanisms, and treatment. , Prog Cardiovasc Dis 48 (2006) 256-69.

4. G.H. Almassi, T. Schowalter, A.C. Nicolosi, A. Aggarwal, T.E. Moritz, W.G. Henderson, R. Tarazi, A.L. Shroyer, G.K. Sethi, F.L. Grover, K.E. Hammermeister, Atrial fibrillation after cardiac surgery: a major morbid event?, Ann Surg 226 (1997) $501-511$.

5. A. Bril, Recent advances in arrhythmia therapy: treatment and prevention of atrial fibrillation, Curr Op in Pharmacol 2 (2002) 154-9.

6. P. Khairy, S. Nattel, New insights into the mechanisms and management of atrial fibrillation, CMAJ 167 (2002) 1012-1020.

7. B.A. Schoonderwoerd, I.C. Van Gelder, D.J. Van Veldhuisen, M.P. Van den Berg, H.J. Crijns, Electrical and structural remodeling: role in the genesis and maintenance of atrial fibrillation, Prog Cardiov asc Dis 48 (2005) 153-68.

8. A.J. Kaumann, Do human atrial 5-HT 4 receptors med iate arrhythmias?, Trends Pharmacol Sci 15 (1994) 451-455.

9. A.J. Workman, A.C. Rankin, Serotonin, $\mathrm{I}_{\mathrm{f}}$ and human atrial arrhythmia, Cardiovasc Res 40 (1998) 436-437.

10. M. Langlois, R. Fischmeister, 5-HT 4 receptor ligands: Applications and new prospects, $\mathrm{J}$ Med Chem 46 (2003) 319-344.

11. O. Blondel, M. Gastineau, Y. Dahmoune, M. Langlois, R. Fischmeister, Cloning, expression, and pharmacology of four human 5-hydroxytryptamine ${ }_{4}$ receptor isoforms produced by alternative splicing in the carboxyl terminus, J Neurochem 70 (1998) 2252- 
2261.

12. H. Ouad id, J. Seguin, A. Dumuis, J. Bockaert, J. Nargeot, Serotonin increases calcium current in human atrial myocytes via the newly described 5-hydroxytryptamine 4 receptors, Mol Pharmacol 41 (1992) 346-351.

13. L. Castro, J. Mialet-Perez, A. Guillemeau, F. Stillitano, O. Zolk, T. Eschenhagen, F. Lezoualc'h, P. Bochet, R. Fischmeister, Differential functional effects of two 5-HT 4 receptor isoforms in adult cardiomyocytes, J Mol Cell Cardiol 39 (2005) 335-344.

14. R. Pino, E. Cerbai, G. Calamai, F. Alajmo, A. Borgioli, L. Braconi, M. Cassai, G.F. Montesi, A. Mugelli, Effect of 5- $\mathrm{HT}_{4}$ receptor stimulation on the pacemaker current $\mathrm{I}_{\mathrm{f}}$ in human isolated atrial myocytes, Cardiovasc Res 40 (1998) 516-522.

15. T. Bach, T. Syversveen, A.M. Kvingedal, K.A. Krobert, T. Brattelid, A.J. Kaumann, F.O. Levy, 5-HT $4\left(\right.$ a) and 5- $\mathrm{HT}_{4(\mathrm{~b})}$ receptors have nearly identical pharmacology and are both expressed in human atrium and ventricle, Naunyn Schmiedebergs Arch Pharmacol 363 (2001) 146-160.

16. T. Brattelid, E. Qvigstad, J.A. Lynham, P. Molenaar, H. Aass, O. Geiran, T. Skomedal, J.B. Osnes, F.O. Levy, A.J. Kaumann, Functional serotonin 5-HT4 receptors in porcine and human ventricular myocardium with increased $5-\mathrm{HT}_{4}$ mRNA in heart failure, Naunyn Schmiedebergs Arch Pharmacol 370 (2004) 157-166.

17. R.G. Schoemaker, X.Y. Du, W.A. Bax, E. Bos, P.R. Saxena, 5-Hydroxytryptamine stimulates human isolated atrium but not ventricle, Eur J Pharmacol 230 (1993) 103105.

18. E. Qvigstad, T. Brattelid, I. Sjaastad, K.W. Andressen, K.A. Krobert, J.A. Birkeland, O.M. Sejersted, A.J. Kaumann, T. Skomedal, J.-B. Osnes, F.O. Levy, Appearance of a ventricular $5-\mathrm{HT}_{4}$ receptor-mediated inotropic response to serotonin in heart failure, Cardiovasc Res 65 (2005) 869-878.

19. E. Qvigstad, I. Sjaastad, T. Brattelid, C. Nunn, F. Swift, J.A. Birkeland, K.A. Krobert, G.O. Andersen, O.M. Sejersted, J.B. Osnes, F.O. Levy, T. Skomedal, Dual serotonergic regulation of ventricular contractile force through 5-HT2A and 5-HT4 receptors induced in the acute failing heart, Circ Res 97 (2005) 268-76. 
20. M.M. Rahme, B. Cotter, E. Leistad, M.K. Wadhwa, R. Mohabir, A.P. Ford, R.M. Eglen, G.K. Feld, Electrophysiological and antiarrhythmic effects of the atrial selective 5-HT receptor antagonist RS-100302 in experimental atrial flutter and fibrillation, Circulation 100 (1999) 2010-2017.

21. A.J. Kaumann, J.A. Lynham, A.M. Brown, Comparison of the densities of 5-HT 4 receptors, $\beta_{1-}$ and $\beta_{2}$-adrenoceptors in human atrium: Functional implications, NaunynSchmied Arch Pharmacol 353 (1996) 592-595.

22. A.D. Medhurst, F. Lezoualc'h, R. Fischmeister, D.N. Middlemiss, G.J. Sanger, Quantitative mRNA analysis of five C-terminal splice variants of the human 5-HT 4 receptor in the central nervous system by TaqMan real time RT-PCR, Mol Brain Res 90 (2001) 125-134.

23. J.B. Grammer, X.R. Zeng, R.F. Bosch, V. Kuhlkamp, Atrial L-type $\mathrm{Ca}^{2+}$-channel, betaadrenoreceptor, and 5-hydroxytryptamine type 4 receptor mRNAs in human atrial fibrillation, Basic Res Cardiol 96 (2001) 82-90.

24. D.M. Bers, Cardiac excitation-contraction coupling, Nature 415 (2002) 198-205.

25. A. Goette, M. Arndt, C. Rocken, A. Spiess, T. Staack, J.C. Geller, C. Huth , S. Ansorge, H.U. Klein, U. Lendeckel, Regulation of angiotensin II receptor subtypes during atrial fibrillation in humans, Circulation 101 (2000) 2678-2681.

26. B.J.J.M. Brundel, R.H. Henning, H.H. Kampinga, I.C. Van Gelder, H.J.G.M. Crijns, Molecular mechan isms of remodeling in human atrial fibrillation, Cardiovasc Res 54 (2002) 315-324.

27. B.J. Brundel, I.C. Van Gelder, R.H. Henning, R.G. Tieleman, A.E. Tu inenburg, M. Wietses, J.G. Grandjean, W.H. Van Gilst, H.J. Crijns, Ion channel remodeling is related to intraoperative atrial effective refractory periods in patients with paroxysmal and persistent atrial fibrillation, Circulation 103 (2001) 684-690.

28. L.P. Lai, M.J. Su, J.L. Lin, F.Y. Lin, C.H. Tsai, Y.S. Chen, S.K.S. Huang, Y.Z. Tseng, W.P. Lien, Down-regulation of L-type calcium channel and sarcoplasmic reticular $\mathrm{Ca}^{2+}$ ATPase mRNA in human atrial fibrillation without significant change in the mRNA of ryanodine receptor, calsequestrin and phospholamban - An insight into the mechanism 
of atrial electrical remodeling, J Am Coll Cardiol 33 (1999) 1231-1237.

29. J. Yamada, T. Ohkusa, T. Nao, M. Yano, S. Kobayashi, K. Hamano, K. Esato, M. Matsuzaki, Up-regulation of inositol 1,4,5 trisphosphate receptor expression in atrial tissue in patients with chronic atrial fibrillation, J Am Coll Cardiol 37 (2001) 11111119.

30. U. Schotten, M. Greiser, D. Benke, K. Buerkel, B. Ehrenteidt, C. Stellbrink, J.F. VazquezJimenez, F. Schoendube, P. Hanrath, M. Allessie, Atrial fibrillation-induced atrial contractile dysfunction: a tachycardiomyopathy of a different sort, Cardiovasc Res 53 (2002) 192-201.

31. D.M. Bers, S.M. Pogwizd, K. Schlotthauer, Upregulated $\mathrm{Na} / \mathrm{Ca}$ exchange is involved in both contractile dysfunction and arrhythmogenesis in heart failure, Basic Res Cardiol 97 Suppl 1 (2002) I36-42.

32. R.F. Bosch, X.R. Zeng, J.B. Grammer, K. Popovic, C. Mewis, V. Kuhlkamp, Ionic mechanisms of electrical remodeling in human atrial fibrillation, Cardiovasc Res 44 (1999) 121-131.

33. J.M. Nerbonne, R.S. Kass, Molecular physiology of card iac repolarization, Physiol Rev 85 (2005) 1205-1253.

34. L.X. Yue, P. Melnyk, R. Gaspo, Z.G. Wang, S. Nattel, Molecular mechanisms underlying ionic remodeling in a dog model of atrial fibrillation, Circ Res 84 (1999) 776-784.

35. B.J.J.M. Brundel, I.C. Van Gelder, R.H. Henning, A.E. Tu inenburg, L.E. Deelman, R.G. Tieleman, J.G. Crandjean, W.H. Van Gilst, H.J.G.M. Crijns, Gene expression of proteins influencing the calcium homeostasis in patients with persistent and paroxysmal atrial fibrillation, Cardiovasc Res 42 (1999) 443-454.

36. L.P. Lai, M.J. Su, J.L. Lin, F.Y. Lin, C.H. Tsai, Y.S. Chen, Y.Z. Tseng, W.P. Lien, S.K. Huang, Changes in the mRNA levels of delayed rectifier potassium channels in human atrial fibrillation, Cardiology 92 (1999) 248-255.

37. U. Schotten, H. Haase, D. Frechen, M. Greiser, C. Stellbrink, J.F. VazguezJimenez, I. 
Morano, M.A. Allessie, P. Hanrath, The L-type $\mathrm{Ca}^{2+}$-channel subunits $\mathrm{a}_{1 \mathrm{C}}$ and $\beta_{2}$ are not downregulated in atrial myocardiurn of patients with chronic atrial fibrillation, J Mol Cell Cardiol 35 (2003) 437-443.

38. R. Gaspo, R.F. Bosch, E. Bou-Abboud, S. Nattel, Tachycardia-induced changes in $\mathrm{Na}^{+}$ current in a chronic dog model of atrial fibrillation, Circ Res 81 (1997) 1045-1052.

39. T. Yagi, J.L. Pu, P. Chandra, M. Hara, P. Danilo, M.R. Rosen, P.A. Boyden, Density and function of inward currents in right atrial cells from chronically fibrillating canine atria, Cardiovasc Res 54 (2002) 405-415.

40. H.M.W. van der Velden, H.J. Jongsma, Cardiac gap junctions and connexins: their role in atrial fibrillation and potential as therapeutic targets, Cardiovasc Res 54 (2002) 270279.

41. A. Elvan, K. Wylie, D.P. Zipes, Pacing-induced chronic atrial fibrillation impairs sinus node function in dogs. Electrophysiological remodeling, Circulation 94 (1996) 29532960.

42. H.M. van der Velden, M.J. van Kempen, M.C. Wijffels, M. van Zijverden, W.A. Groenewegen, M.A. Allessie, H.J. Jongsma, Altered pattern of connexin40 dis tribution in persistent atrial fibrillation in the goat, J Cardiovasc Electrophysiol 9 (1998) 596-607.

43. E. Dupont, Y.S. Ko, S. Rothery, S.R. Coppen, M. Baghai, M. Haw, N.J. Severs, The gap-junctional protein connexin 40 is elevated in patients susceptible to postoperative atrial fibrillation, Circulation 103 (2001) 842-849. 


\section{Figure Legends}

Fig. 1. 5-HT $\mathrm{H}_{4}$ receptor splice variant mRNA expression in right atrial appendages of patients with sinus rhythm, or developing acute or chronic atrial fibrillation. mRNA expression profiles are shown for the $5-\mathrm{HT}_{4(\mathrm{a})}, 5-\mathrm{HT}_{4(\mathrm{~b})}, 5-\mathrm{HT}_{4(\mathrm{c})}$ and $5-\mathrm{HT}_{4(\mathrm{~g})}$ receptor isoforms. TaqMan RT-PCR analysis was performed using total RNA extracted from each patient. Data are expressed as arbitrary fluorescent units normalized to cyclophilin, GAPDH, and RL-19 to correct for RNA quantity and integrity, and are mean values \pm SEM. SR, sinus rhythm $(\mathrm{n}=11) ; \operatorname{AAF}$, acute $\mathrm{AF}(\mathrm{n}=5) ; \mathrm{CAF}$, chronic $\mathrm{AF}(\mathrm{n}=6)$.

Fig. 2. Comparison of the expression levels of G-protein coupled receptors and calcium handling proteins in patients with sinus rhythm versus patients developing acute or chronic atrial fibrillation. mRNA expression of the different genes were determined by quantitative TaqMan RT-PCR using primer/probe sets as described in Supplementary Data Supplementary Table 1. Data are expressed as fold over sinus rhythm (SR) normalised to cyclophilin, GADPH and RL-19. Results are mean values \pm SEM. AAF, acute AF; CAF, chronic AF.

Fig. 3. mRNA expression analysis of ion channels in atrial fibrillation. Change in gene expression was analyzed by quantitative TaqMan RT-PCR. Histograms show the relative mRNA abundance of hyperpolarization-activated inward channels and outward $\mathrm{K}^{+}$channels (A), and $\mathrm{Ca}^{2+}$ and $\mathrm{Na}^{+}$inward and gap junction channels (B). Data are expressed as fold over sinus rhythm (SR) normalised to housekeeping genes. Results are mean values \pm SEM. AAF, acute AF; CAF, chronic AF. 
Table 1. Characteristics of the patients

\begin{tabular}{|c|c|c|c|c|}
\hline & $\begin{array}{c}\text { Sinus } \\
\text { rhythm }\end{array}$ & Acute & Chronic & $\begin{aligned} & \text { Acute } \\
&+ \text { Chronic } \\
&\end{aligned}$ \\
\hline Total number & 11 & 5 & 6 & 11 \\
\hline $\operatorname{Sex}(\mathrm{M} / \mathrm{F})$ & $11 / 0$ & $5 / 0$ & $4 / 2$ & $9 / 2$ \\
\hline Age (years) & $67 \pm 2$ & $68 \pm 4$ & $70 \pm 3$ & $69 \pm 2$ \\
\hline Atrial fibrillation & Absent & Post-CABG & $\begin{array}{l}\text { Permanent } \\
(>1 \text { year })\end{array}$ & \\
\hline \multicolumn{5}{|l|}{ Cardiac disease } \\
\hline Coronary artery disease & 11 & 5 & 4 & \\
\hline Aortic valve disease & 0 & 0 & 2 & \\
\hline Mitral valve disease & 0 & $2^{\mathrm{a}}$ & 1 & \\
\hline \multicolumn{5}{|l|}{ Left ventricular function } \\
\hline Normal & 2 & 2 & 1 & \\
\hline Mild to moderate dysfunction & 3 & 1 & 4 & \\
\hline Severe dysfunction & 1 & 0 & 0 & \\
\hline Not available & 5 & 2 & 0 & \\
\hline LVEF (\%) & $45 \pm 5$ & $55 \pm 10$ & $42 \pm 5$ & $45 \pm 5$ \\
\hline Hypertension (N. patients) & 7 & 2 & 0 & 2 \\
\hline \multicolumn{5}{|l|}{ Medication $(\%)$} \\
\hline Diuretics & - & 20 & 100 & 64 \\
\hline Digoxin & - & - & 67 & 36 \\
\hline Antiarrhythmics & 18 & 20 & 17 & 18 \\
\hline ACE-I/ARB & 18 & 20 & 67 & 46 \\
\hline Nitro- vasodilators & 82 & 100 & 33 & 64 \\
\hline Beta-blockers & 27 & 60 & 17 & 36 \\
\hline Calcium Antagonists & 64 & 40 & - & 18 \\
\hline Anticoagulants & 46 & 20 & 50 & 36 \\
\hline Aspirin & 46 & 80 & 33 & 55 \\
\hline
\end{tabular}

LVEF, left ventricular ejection fraction; ACE-I, angiotens in converting enzyme-inhibitors;

ARB, angiotensin II receptor blockers. ${ }^{a}$ Mitral insufficiency 

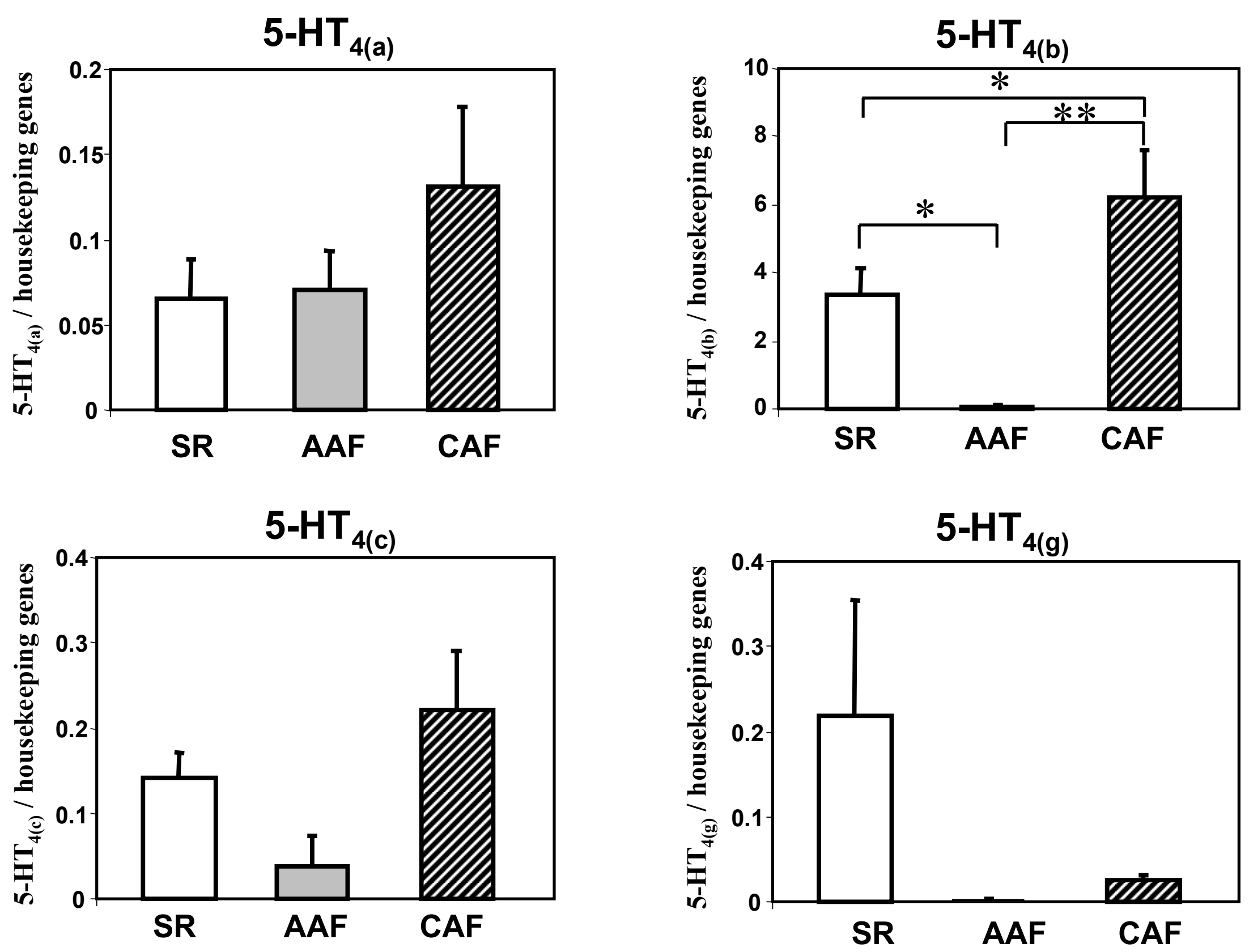

Figure 1 


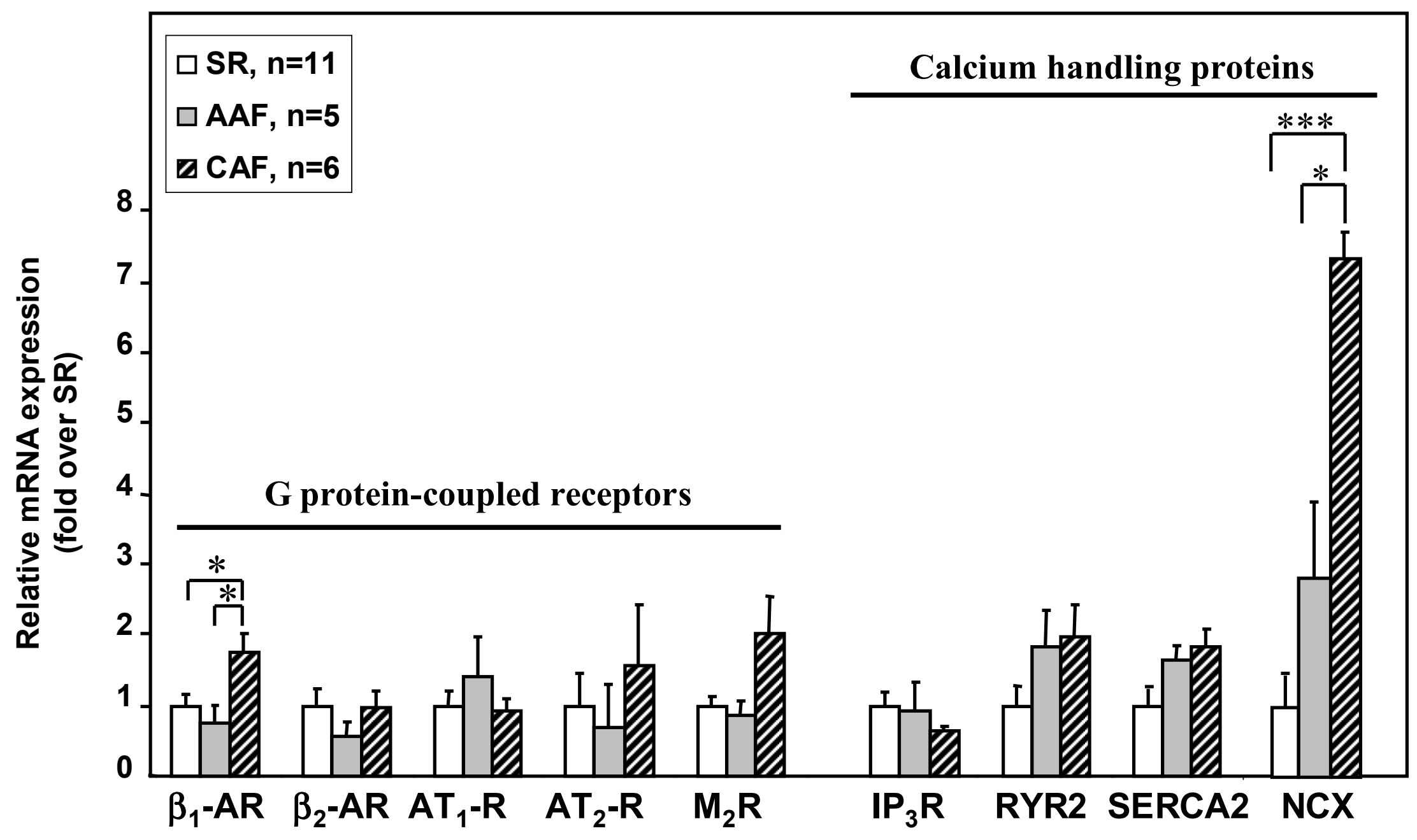

Figure 2 
A

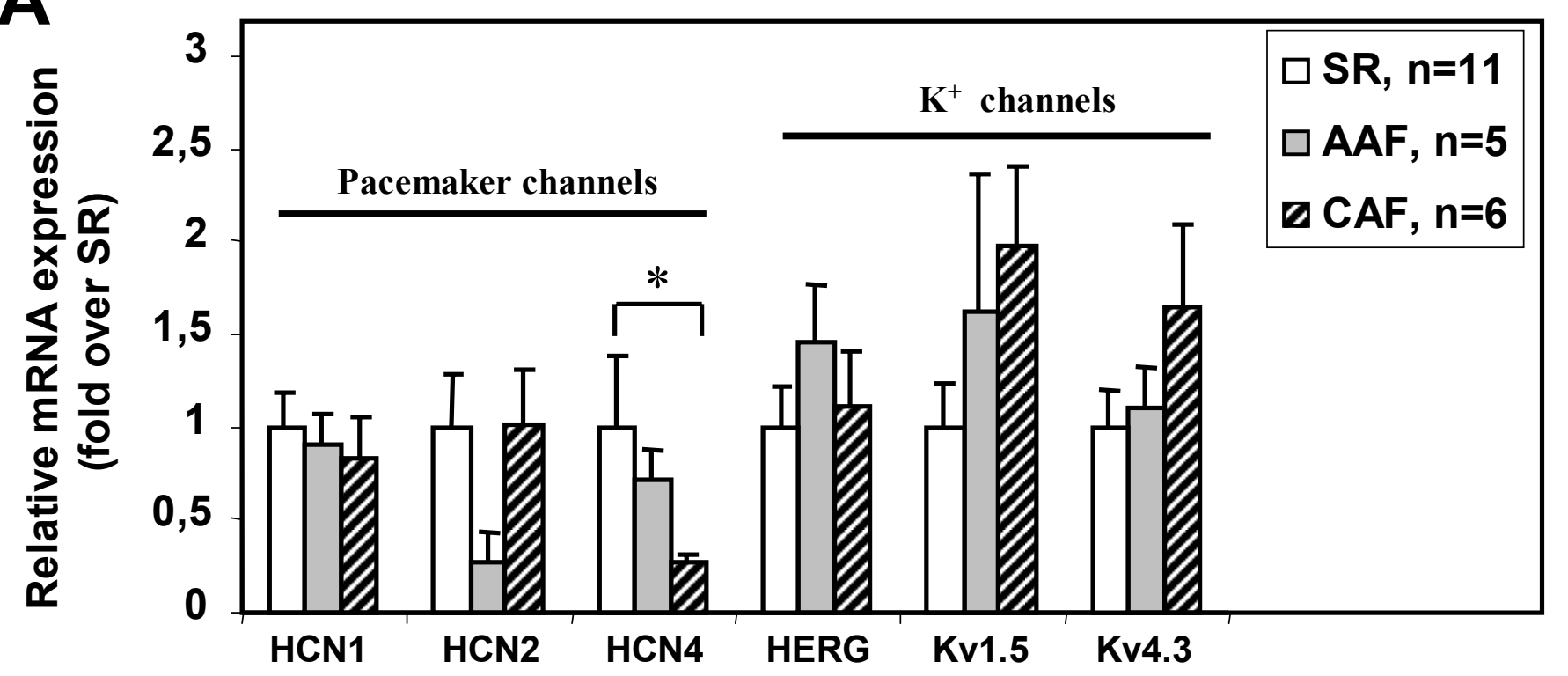

B

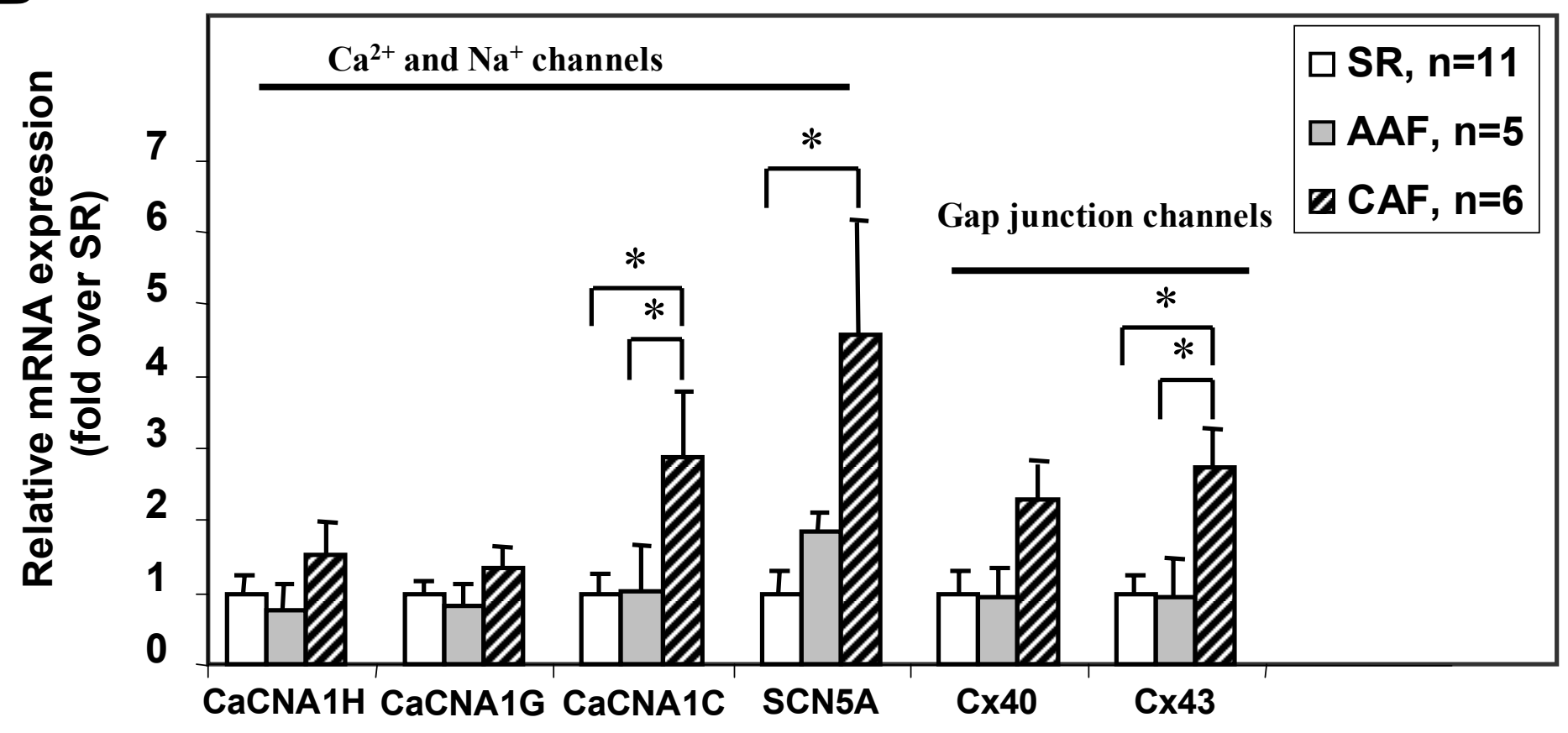

Figure 3 


\title{
DATA SUPPLEMENT TO MANUSCRIPT
}

\author{
Quantitative mRNA analysis of serotonin 5-HT 4 receptor isoforms, calcium handling \\ proteins and ion channels in human atrial fibrillation
}

Frank Lezoualc'h, Klaudia Steplewski, Laura Sartiani, Alessandro Mugelli, Rodolphe Fischmeister, Antoine Bril

\section{Methods}

\section{RNA Preparation and Real-time Quantitative RT-PCR}

Total RNA was prepared from human atrial tissues using the Trizol RNA purification system (Life Technologies Inc., Cergy-Pontoise, France). After purification RNA was treated with DNase I (Life Technologies Inc., Cergy-Pontoise, France) to remove genomic DNA. RNA integrity was confirmed using agarose gel electrophoresis. Five $\mu \mathrm{g}$ of total RNA was then reverse transcribed with oligo(dt) primers and Superscript reverse transcriptase (Life Technologies Inc., Cergy-Pontoise, France). Primer and probe sets presented in Table 1 were designed using Primer Express V1.0 Software (P.E Applied Biosystems). TaqMan RT-PCR analysis of human tissue was performed as previously described (1). The cDNA prepared from 5ug total RNA was arrayed into 96-well plates in duplicates (P.E Applied Biosystems) and each well contained the equivalent of $25 \mathrm{ng}$ of total RNA. Quantification of mRNA was achieved by using known plasmid/genomic DNA standards included in each run, excepted for the $\beta_{1}$-adrenergic receptor, connexin $(\mathrm{Cx}) 40(\mathrm{Cx} 40)$, the muscarinic acetylcholine receptor type $2\left(\mathrm{M}_{2} \mathrm{R}\right)$, the sarcolemmal $\mathrm{Na}^{+} / \mathrm{Ca}^{2+}$ exchanger $(\mathrm{NCX})$, the ryanodine receptor type 2 (RYR2), the cardiac sarcoplasmic reticulum $\mathrm{Ca}^{2+}$ ATPase (SERCA2a) and T-type $\mathrm{Ca}^{2+}$ 
channel $\alpha_{1 \mathrm{H}}(\mathrm{CaCNA} 1 \mathrm{H})$ and $\alpha_{1 \mathrm{G}}(\mathrm{CaCNA} 1 \mathrm{G})$ subunit mRNA whose relative abundances were calculated with the formula POWER $(10,-1 *(((\mathrm{H} 10-40)) / 3.5))$. In addition, to correct for variations in RNA and/or cDNA quality and quantity, average of transcript levels of the target genes were normalized to the average of the housekeeping genes, cyclophilin, glyceraldehyde 3-phosphate dehydrogenase (GADPH), and ribosomal protein L-19 (RL-19). The abundance of mRNA for these three genes remains stable regardless of the cardiac status (data not shown).

\section{Statistical analysis}

One way ANOVA, followed by Newman-Keuls post hoc test was used to assess the differences between the experimental groups. Values of $\mathrm{P}<0.05$ were considered significant. $*, \mathrm{P}<0.05 ; * *, \mathrm{P}<0.01$. 
Supplementary Table 1. Oligonucleotide sequences for sense (s) and antisense (a) primers and TaqMan probes (p).

\begin{tabular}{|c|c|c|c|}
\hline & \multicolumn{2}{|c|}{$\begin{array}{l}\text { Accession number } \\
\text { in Genbank }\end{array}$} & Sequence $\left(5^{\prime}-3^{\prime}\right)$ \\
\hline \multicolumn{4}{|l|}{ Housekeeping genes } \\
\hline ß-actin & M10277 & & in Ref. (2) \\
\hline \multirow[t]{3}{*}{ Cyclophylin } & D63864 & $\mathrm{s}$ & CATCTGCACTGCCAAGACTGA \\
\hline & & $\mathrm{a}$ & TGCCTTCTTTCACTTTGCCA \\
\hline & & $\mathrm{p}$ & CACCACATGCTTGCCATCCAACCA \\
\hline \multirow[t]{3}{*}{ GAPDH } & J04038 & s & CAAGGTCATCCATGACAACTTTG \\
\hline & & $\mathrm{a}$ & GGGCCATCCACAGTCTTCTG \\
\hline & & $\mathrm{p}$ & ACCACAGTCCATGCCATCACTGCCAT \\
\hline \multirow[t]{3}{*}{ RL-19 } & AY157980 & s & CAAGCGGATTCTCATGGAACA \\
\hline & & $\mathrm{a}$ & TGGTCAGCCAGGAGCTTCTT \\
\hline & & $\mathrm{p}$ & TCCACAAGCTGAAGGCAGACAAGGC \\
\hline \multicolumn{4}{|l|}{ GPCRs } \\
\hline $5-\mathrm{HT}_{4(\mathrm{a})}$ & Y08756 & & in Ref. (2) \\
\hline $5-\mathrm{HT}_{4(\mathrm{~b})}$ & Y12505 & & in Ref. (2) \\
\hline $5-\mathrm{HT}_{4(\mathrm{c})}$ & Y12506 & & in Ref. (2) \\
\hline $5-\mathrm{HT}_{4(\mathrm{~d})}$ & Y12507 & & in Ref. (2) \\
\hline $5-\mathrm{HT}_{4(\mathrm{~g})}$ & AJ011371 & & in Ref. (2) \\
\hline \multirow[t]{3}{*}{$B_{1}-\mathrm{AR}$} & AF169007 & s & CCGCCTCTTCGTCTTCTTCA \\
\hline & & $\mathrm{a}$ & TGCGGCAGTAGATGATGGG \\
\hline & & $\mathrm{p}$ & TGGGCTACGCCAACTCGGCCTT \\
\hline \multirow[t]{3}{*}{$\beta_{2}-\mathrm{AR}$} & NM_000024 & s & GCCGAAAGTTCCCGTACGTC \\
\hline & & $\mathrm{a}$ & ACACTCAGCTTGTCGGGTGC \\
\hline & & $\mathrm{p}$ & СTTCTTCAGAGCACGGGCTGGAACTGG \\
\hline \multirow{3}{*}{$\begin{array}{l}\text { Angiotensin II type } 1 \\
\text { receptor }\left(A T_{1}-\mathrm{R}\right)\end{array}$} & AF245699 & s & CTGGATGTATTGATTCAACTAGGC \\
\hline & & $\mathrm{a}$ & ATGGTGATAGGCATGGCCG \\
\hline & & $\mathrm{p}$ & CGTGACTGTAGAATTGCAGATATTGTGGACA \\
\hline \multirow{3}{*}{$\begin{array}{l}\text { Angiotensin II type } 2 \\
\text { receptor }\left(\mathrm{AT}_{2}-\mathrm{R}\right)\end{array}$} & U20860 & s & CCAACAGCTGCGTTAATCCG \\
\hline & & $\mathrm{a}$ & GGAACCCTAAACACACTGCGG \\
\hline & & $\mathrm{p}$ & TGTATTGTTTTGTTGGAAACCGGTTCCA \\
\hline \multirow[t]{3}{*}{$\mathrm{M}_{2} \mathrm{R}$} & NM_000739 & $\mathrm{s}$ & ACCACCGTGGAGGTAGTGGG \\
\hline & & $\mathrm{a}$ & ATCTTCACAATCTTGCGGGC \\
\hline & & $\mathrm{p}$ & TCAGGTCAGAATGGAGATGAAAAGCAGA \\
\hline \multicolumn{4}{|c|}{ Calcium-handling proteins } \\
\hline Inositol $1,4,5$ & AB012610 & $\mathrm{s}$ & CTGGAGAAGAATGCCATGCG \\
\hline \multirow{2}{*}{\multicolumn{2}{|c|}{ triphosphate receptor (IP3R) }} & $\mathrm{a}$ & TTGCATCATTGTCACCCTCG \\
\hline & & $\mathrm{p}$ & TCCTTGGATGCTGCAGGAAATGAAGGG \\
\hline \multirow[t]{3}{*}{ RYR2 } & XM_001778 & s & TGGCATAAACTACTGTCCAAGCAG \\
\hline & & $\mathrm{a}$ & AAGAGATTGACAGCCCGATGC \\
\hline & & $\mathrm{p}$ & AAAGGGCTGTTGTAGCCTGCTTCCGGA \\
\hline \multirow[t]{3}{*}{ SERCA2a } & XM_027104 & s & TCGAACCCTTGCCACTCATC \\
\hline & & $\mathrm{a}$ & AGGTTCCAGGTAGTTGCGGG \\
\hline & & $\mathrm{p}$ & ATGGTGCTGAAAATCTCCTTGCCCGTG \\
\hline \multirow[t]{3}{*}{ SLC8A1 (NCX) } & NM_021097.1 & s & GGCCAGAAATCGGAGGTGAG \\
\hline & & $\mathrm{a}$ & GGCAGTAGGCCTCCAGGG \\
\hline & & $\mathrm{p}$ & CTGCCAAGCTCCTCACATCCTGCCTCT \\
\hline \multicolumn{4}{|c|}{ Hyperpolarization-activated inward currents } \\
\hline \multirow[t]{3}{*}{$\mathrm{HCN} 1$} & AF064876 & $\mathrm{s}$ & TCCCGCATGAGGACACAATC \\
\hline & & $\mathrm{a}$ & GTGACAGGATGGCTGATGGC \\
\hline & & $\mathrm{p}$ & ACCAGCCTGTCTCACAGCAACCTGCAC \\
\hline
\end{tabular}




\begin{tabular}{|c|c|c|c|}
\hline \multirow[t]{3}{*}{ HCN2 } & NM_001194 & s & CAGGGACTCGGCCTCACC \\
\hline & & $\mathrm{a}$ & CACAAGTTGGACGAGAGGCG \\
\hline & & $\mathrm{p}$ & CTGGACCCCCAGGACTCCGCG \\
\hline \multirow{3}{*}{ HCN4 } & $\mathrm{AJ} 238850$ & $\mathrm{~s}$ & CCTCAGGTTCTTTGCCACCC \\
\hline & & a & GATTGGACGGCAGTTTGGAG \\
\hline & & $\mathrm{p}$ & TGTTTGGGGCAAGAGCCACCTCTTCTG \\
\hline \multicolumn{4}{|c|}{ Repolarizing outward $\mathrm{K}^{+}$currents } \\
\hline \multirow[t]{3}{*}{ HERG } & AF363636 & s & ССТCCTCCATGGCCTCTTC \\
\hline & & $\mathrm{a}$ & CACGCCATGAACTGGGAAA \\
\hline & & $\mathrm{p}$ & CCTGCCCATGCTCTGTGTGTATTGCA \\
\hline \multirow[t]{3}{*}{ Kv1.5 (KCN5) } & M83254 & s & GGGAAACGGATCACGAGGAG \\
\hline & & $\mathrm{a}$ & TGTCTGCATTCTCCAGGGTCC \\
\hline & & $\mathrm{p}$ & GACAGAGGAGTCCAGCGGAAGGTCAGC \\
\hline \multirow[t]{3}{*}{ Kv4.3 } & AF205857 & s & TCACCACAGCCATCATCAGC \\
\hline & & a & GGAAGGAATGTTCGTGTTGGG \\
\hline & & $\mathrm{p}$ & CAGCGCTAACCCCAGAGGGGGAAAGTC \\
\hline \multicolumn{4}{|c|}{$\mathrm{Ca}^{2+}$ inward currents } \\
\hline \multirow[t]{3}{*}{$\mathrm{I}_{\mathrm{Ca}, \mathrm{T} \mathrm{H}}\left(\alpha_{1 \mathrm{H}}\right.$ sub-unit $)$} & NM_018896 & s & GAATCAGAGCCTCCCATGCC \\
\hline & & a & GGACCCTGGTTTCTCCAGAGG \\
\hline & & $\mathrm{p}$ & AAGAGGCGGGGGCTGTACCTCACAGTC \\
\hline \multirow[t]{3}{*}{$\mathrm{I}_{\mathrm{Ca}, \mathrm{T} \mathrm{G}}\left(\alpha_{1 \mathrm{G}}\right.$ sub-unit $)$} & AF051946 & s & GCAGATGAGGTGCATCTTTGG \\
\hline & & a & TCAGTCAGGCTCCGTCTTGTC \\
\hline & & $\mathrm{p}$ & TCACTCCCAGCCAGCAGATACCAGC \\
\hline \multirow[t]{3}{*}{$\mathrm{I}_{\mathrm{Ca}, \mathrm{L}}\left(\alpha_{1}\right.$ sub-unit $)$} & L29529 & s & GGCGCCCTCTTACCCTTTG \\
\hline & & a & AGCTCCTCCTCACTCGGTCG \\
\hline & & $\mathrm{p}$ & GCGAAGAGGACGCGGGCTGTGT \\
\hline \multicolumn{4}{|l|}{$\mathrm{Na}^{+}$inward currents } \\
\hline \multirow[t]{3}{*}{$\mathrm{I}_{\mathrm{Na}}(\alpha$ sub-unit $)$} & M77235 & s & AGCCACCAGCGATAACCTCC \\
\hline & & a & GACTCACGGTCCCTGTCCG \\
\hline & & $\mathrm{p}$ & CACAGTGAAGATCTCGCCGACTTCCCC \\
\hline \multicolumn{4}{|l|}{ Connexins } \\
\hline \multirow[t]{3}{*}{$\mathrm{Cx} 40$} & ВC013313 & s & CAACCTGGTCACCGAGCAAG \\
\hline & & a & GACTCCATTGGGCACCTCAG \\
\hline & & $\mathrm{p}$ & AGGTCAGGAGCAGACTCCTGGGGAAGG \\
\hline \multirow[t]{3}{*}{$\mathrm{Cx} 43$} & AF151980 & s & CTAGCCATTGTGGACCAGCG \\
\hline & & a & ATCTCCAGGTCATCAGGCCG \\
\hline & & $\mathrm{p}$ & ACCTTCAAGCAGAGCCAGCAGTCGTGC \\
\hline
\end{tabular}




\section{Supplementary References}

1. H.M. Sarau, R.S. Ames, J. Chambers, C. Ellis, N. Elshourbagy, J.J. Foley, D.B. Schmidt, R.M. Muccitelli, O. Jenkins, P.R. Murdock, N.C. Herrity, W. Halsey, G. Sathe, A.I. Muir, P. Nuthulaganti, G.M. Dytko, P.T. Buckley, S. Wilson, D.J. Bergsma, D.W. Hay, Identification, molecular cloning, expression, and characterization of a cysteinyl leukotriene receptor., Mol Pharmacol 56 (1999) 657-663.

2. A.D. Medhurst, F. Lezoualc'h, R. Fischmeister, D.N. Middlemiss, G.J. Sanger, Quantitative mRNA analysis of five C-terminal splice variants of the human 5- $\mathrm{HT}_{4}$ receptor in the central nervous system by TaqMan real time RT-PCR., Mol Brain Res 90 (2001) 125-134. 